\title{
KERANGKA EKONOMI MAKRO DAERAH KOTA BITUNG DI KAWASAN PENGEMBANGAN EKONOMI TERPADU
}

\author{
William Agustinus Areros \\ Jurusan Ilmu Administrasi, Fakultas Ilmu Sosial dan Politik Unsrat Manado \\ E-mail : areros.william@yahoo.co.id
}

\begin{abstract}
ABSTRAK. Kota Bitung yang berada dalam Kawasan Pengembangan Ekonomi Terpadu Manado - Bitung telah menunjukkan banyak keberhasilan pembangunan yang tercermin dari laju pertumbuhan ekonomi yang dicapai serta banyaknya investor yang berinvestasi. Akan tetapi juga juga masih diperhadapkan dengan kepadatan penduduk, transformasi struktur ekonomi, meningkatnya angkatan percari kerja, persaingan antar kekuatan ekonomi. Dari kenyataan empiris dan urgennya permasalahan maka perlu melakukan analisis atas kerangka ekonomi makro Kota Bitung di Kawasan Pengembangan Ekonomi Terpadu dalam pengembangan ilmu kebijakan pembangunan daerah sektor ekonomi dan sebagai reverensi bagi pemerintah daerah dalam menetapkan kerangka pembangunan ekonomi daerah. Penelitian ini menggunakan desain penelitian kualitatif yang menjadikan peneliti sebagai instrumen. Data diperoleh dari wawancara, observasi dan penggunaan data sekunder serta dianalsisi melalui reduksi data, interpretasi, penyajian data dan penarikan kesimpulan. Dari penelitian yang dilakukan ditemukan bahwa kerangka ekonomi makro Kota Bitung di Kawasan Pengembangan Ekonomi Terpadu dibagi pada sektor primer terdiri dari pertanian, perambangan dan galian, sektor sekunder yang mencakup sektor industri, lisrik dan air bersih dan bangunan/ konstruksi, serta sektor tersier yang mencakup sektor perdagangan, hotel dan restoran, angkuan dan komunikasi, bank dan lembaga keuangan, persewaan dan jasa perusahaan serta sektor jasa lainnya. Perbaikan pada ketiga kelompok sektor diatas perlu dilakukan dengan mengurangi pengangguran dan meningkatkan kualitas tenaga kerja, menurunkan jumlah penduduk miskin, meningkakan produksi pada sektor angkutan, komunikasi, industri pengolahan dan perikanan serta melakukan pembenahan pada berbagai kendala yang menghambat peningkatan produksi dan investasi.
\end{abstract}

Kata kunci: Pertumbuhan, ekonomi makro, kawasan pengembangan.

ABSTRACT. Bitung town located in the Integrated Economic Development Zone Manado - Bitung has shown much success development reflected economic growth rates achieved and the number of investors who invest. But it is also still confronted with a density of population, the transformation of the economic structure, increasing labor force percari, competition between economic power. From the empirical reality and urgency of the problems it is necessary to perform analysis of the macro-economic framework in Bitung Integrated Economic Development Zone in the development of regional development policies and economic sectors as reverensi for local government in setting the framework of regional economic development. This study uses a qualitative research design that makes the researcher as an instrument. Data obtained from interviews, observation and the use of secondary data and dianalsisi through data reduction, interpretation, data presentation and conclusion. From this research it was found that the macroeconomic framework of Bitung in Integrated Economic Development Zone is divided in the primary sector comprising agricultural, perambangan and excavation, the secondary sector. Improvements to the third sector groups above should be done to reduce unemployment and improve the quality of labor, decrease the number of poor, improved its production in the sectors of transport, communications, industrial processing and fisheries as well as to make improvements on a variety of obstacles that hinder the increase of production and investment and by the growing climate investment.

Key words: growth, macroeconomics, development zone

\section{PENDAHULUAN}

Penetapan KawasanPengembanganEkonomiTerpadu (KAPET) dilakukan melalui Keputusan Presiden Nomor 89 Tahun 1996 dan kemudian disempurnakan menjadi Keputusan Presiden Nomor 9 Tahun 1998 dan sesuai dengan semangat otonomi daerah disempurnakan kembali melalui Keputusan Presiden Nomor 150 Tahun 2000 tentang Kawasan Pengembangan Ekonomi Terpadu (KAPET) dilakukan dalam rangka upaya pemerataan pembangunan dan hasil-hasilnya. Pengambilan langkah dan kebijakan ini untuk memacu pertumbuhan ekonomi dibeberapa wilayah di Indonesia khususnya di wilayah Timur Indonesia melalui pembentukan kawasan andalan sebagai pusat-pusat pertumbuhan ekonomi.
Kawasan Pengembangan Ekonomi Terpadu (KAPET) yang ditetapkan dengan memeperhatikan sektor unggulan yang ada dalam kawasan andalan dirumuskan berdasarkan struktur ekonomi daerah yang berguna memberikan kontribusi terhadap pertumbuhan ekonomi nasional melalui daya dorong untuk menghidupkan kawasan sekitarnya dalam hubungan saling terkait. Strategis pembangunan kawasan pengembangan ekonomi terpadu yang ditetapkan secara nasional diupayakan untuk mewujudkan pertumbuhan kawasan yang lebih harmoni, sehingga dapat memberikan manfaat kepada masyarakat demi pembangunan berkelanjutan. Dalam merealisasikan strategi kawasan pengembangan ekonomi terpadu juga diarahkan pada upaya meng-hidupkan infrastruktur wilayah yang meliputi trans-portasi, prasarana air bersih, listrik, dan lainnya. 
Dengan demikian Kawasan Pengembangan Ekonomi Terpadu (KAPET) dapat dilihat sebagai kawasan "pertumbuhan" yang berdimensi luas karena mencakup sektor usaha yang strategis, sehingga dapat menarik minat dari investor untuk melakukan usaha di daerah ini dalam konteks pengembangan sektor potensial seperti perikanan laut, perkebunan, dan lainnya. Hal ini menjadi perhatian dalam pengembangan strategi pembangunan kawasan pengembangan kawasan ekonomi terpadu karena investasi pemerintah sangat terbatas untuk itu peran sektor swasta dan masyarakat perlu menunjukan peran yang lebih positif agar pengembangan kawasan andalan mampu mendukung perkembangan ekonomi daerah dan akhirnya akan dapat mendorong pertumbuhan dan pemerataan kegiatan ekonomi secara nasional.

Kawasan Pengembangan Ekonomi Terpadu (KAPET) yang ditetapkan berjumlah 13 kawasan andalan untuk pengembangan yang salah satunya adalah Kawasan Pengembangan Ekonomi Terpadu (KAPET) Manado Bitung di Provinsi Sulawesi Utara. Kawasan andalan ditentukan berdasarkan potensi dan sumberdaya alam yang bisa dikembangkan untuk meningkatkan pertumbuhan kawasan, keterkaitan antar sector dan antar kawasan sehingga pembangunan di Kawasan Timur Indonesia menjadi satu kesatuan yang terkait dengan Kawasan Barat Indonesia dalam satu kesatuan ruang nasional yang terintegrasi.

Kota Bitung merupakan salah satu pemerintah kota yang ada di Provinsi Sulawesi Utara dengan luas wilayah $304 \mathrm{~km}^{2}$ merupakan pintu gerbang jalur laut dengan berbagai aktivitas perdagangannya yang didukung dengan sumber daya alam yang cukup. Kota Bitung dengan letak yang strategis ini berada dalam Kawasan Pengembangan Ekonomi Terpadu (KAPET) harus diakui telah menunjukkan banyak keberhasilan pembangunan yang tercermin dari laju pertumbuhan ekonomi yang dicapai serta banyaknya investor yang berinvestasi.Akan tetapijuga Kota Bitung diperhadapkan dengan berbagai tantangan dan dinamika lingkungan seperti kepadatan penduduk, terjadinya transformasi struktur ekonomi dari sector pertanian ke sector non pertanian menuntut pemerintah dan masyarakat serta stake holders pembangunan untuk merancang dan melaksanakan pembangunan dengan mengarahkan pada skala prioritas yang dapat menggerakkan roda perekonomian rakyat dan menjamin keberlangsungan pembangunan yang berkelanjutan.

Kondisi lainnya yang juga dihadapi oleh Kota Bitung adalah meningkatnya usia produktif yang adalah merupakan angkatan percari kerja yang potensial sementara pengelola tenaga kerja mulai bergeser dari sector primer ke sector sekunder. Kenyataan lainnya juga yaitu terjadinya kemajuan teknologi informasi dan adanya efek globalisasi yang menciptakan persaingan antar kekuatan ekonomi semakin meningkat menuntut adanya proses pembangunan yang semakin efisien serta menghasilkan produk dengan daya saing yang semakin menjadi tantangan pembangunan kedepan.

Memperhatikan berbagai potensi yang dimiliki serta tantangan yang dihadapi oleh Kota Bitung menuntut adanya kerangka ekonomi yang mampu menjadikan Kota Bitung yang semakin baik yang terlihat pada pemerataan pembangunan dan hasil-hasilnya. Dan dalam upaya memberikan peluang kepada dunia usaha berperan serta dalam kegiatan dan mendorong terbentuknya suatu kawasan yang berperan sebagai penggerak utama (prime mover) pengembangan wilayah maka diperlukan kerangka ekonomi Kota Bitung yang kuat melalui adanya pertumbuhan ekonomi baik.

Dari kenyataan empiris dan urgennya permasalahan yang dihadapi dalam kerangka kebijakan pembangunan daerah maka penting dilakukannya suatu pengkajian secara ilmiah guna melakukan analisis atas kerangkaekonomimakroKotaBitungDiKawasanDaerah Pengembangan Ekonomi Ter-padu dalam pengembangan ilmu dan pengetahuan kebijakanpembangunan daerah sector ekonomi. Serta hasilnya dapat dijadikan pijakan bagi pemerintah daerah dalam menetapkan kerangka pembangunan ekonomi daerah.

\section{METODE}

Penelitian ini menggunakan desain penelitian kualitatif yang menjadikan peneliti sebagai instrumen dan disesuaikan dengan situasi yang wajar dalam kaitannya dengan pengumpulan data yang pada umumnya bersifat kualitatif, lihat Mathew 1992. Pendekatan kualitatif dicirikan oleh tujuan penelitian yang berupaya memahami gejala-gejala pada pembentukan kerangka ekonomi makro Kota Bitung yang tidak memerlukan kuantifikasi, karena gejala tidak memungkinkan untuk diukur secara tepat. Melalui desain ini dapat diperoleh gambaran fenomena, fakta, sifat serta hubungan fenomena tentang kerangka ekonomi makto Kota Bitung yang berada di Kawasan Pengembangan Ekonomi Terpadu secara utuh dan multi demensional sehingga dilakukan kategorisasi dan jawaban pertanyaan penelitian sebagai temuan penelitian. Informan yang diambil berjumlah 10 orang yaitu pemerintah Kota Bitung yang berhubungan dengan bidang perekonomian dan didukung dengan observasi dan penggunaan data sekunder. Analisis data dilakukan melalui reduksi data atau mengorganisir data menurut satuan konsep yang dimaknai melalui interpretasi secara mendalam dengan cara mengungkapkan makna yang terkandung pada data dan dilanjutkan dengan penyajian data dan penarikan kesimpulan (Miles and Haberman, 1994).

\section{HASIL DAN PEMBAHASAN}

Kota Bitung terletak pada posisi geogerafis

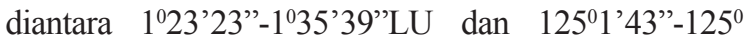
18'13'BT mempunya luas daratan $304 \mathrm{Km}^{2}$ dan luas 
lautan 439,8 Km berada di Kawasan Pengembangan Ekonomi Terpadu (KAPET) dan ditetapkan sebagai kawasan ekonomi khusus dalam kerangka ekonomi makro tercermin dari enam indikator yaitu pertumbuhan ekonomi, inflasi, produk domestik bruto, pendapatan perkapita dan pemerataan distribusi pendapatan, tenaga kerja dan pengangguran serta keuangan daerah (Bappeda, 2010).

Pemahaman atas kerangka ekonomi makro yang secara konsepual dipahami melalui sumber pertumbuhan ekonomi suatu negara atau daerah/wilayah dapat dilihat dari tiga pendekatan yaitu pendekatan faktor produksi, pendekatan sektor dan pendekatan pengeluaran (Farida, 2011). Pertumbuhan ekonomi Kota Bitung dari tahu ke tahun mengalami peningkatan dan hal ini diprediksi oleh pelaku ekomoni dan pemerintah daerah akan terus meningkat. Di lihat secara sektoral bahwa kontribusi yang paling tinggi pertumbuhannya adalah pada sektor angkutan dan komuniasi yang perumbuhannya mengalami peningkatan sejak ahun 2008 sebesar $25,17 \%$, sedangkan perumbuhan yang paling kecil ada pada sektor listrik, gas dan air bersih dengan pertumbuhan yang hanya $0,36 \%$.

Adanya peningkatan perumbuhan ekonomi pada sektor angkutan dan komunikasi lebih disebabkan oleh adanya pelabuhan laut dan pelabuhan peti kemas di Kota Bitung yang didukung dengan dikembangkannya sektor perdagangan, hotel, restoran serta dipacunya sektor pariwisata. Dengan adanya peningkatan ini maka diperlukannya perhatian yang serius karena sektor ini merupakan penyumbang terbesar pada pembentukan PDRB maupun sektor lainnya.

Pada kerangka ekonomi inflasi, seperti halnya kabupaten/kota lainnya yang ada di Sulawesi Utara, inflasi Kota Bitung mengikuti kondisi inflasi Kota Manado karena Kota Manado adalah satu dari 45 kota di Indonesia yang dihitung perkembangan inflasinya. Sementara perbedaan harga di Kota Bitung dengan Kota Manado tidak terlalu signifikan. Inflasi yang dipahami sebagai adanya kenaikan harga secara umum dan terus menerus yang secara nyata banyak berkaitan dengan nilai tukar terhadap dolar AS, kenaikan harga kebuuhan bahan pokok, bencana alam, kenaikan kaji ASN serta meningkatnya aktivitas infesasi menjadi faktor utama pembentukan dan perkembangan tingkat inflasi.

Secara tahunan inflasi Kota Manado termasuk Kota Bitung cenderung mengalami rand peningkatan dari posisi deflasi $0,01 \%$ (yoy) seperti pada triwulan III-2009 menjadi 2,31\% (yoy) pada triwulan IV2009. Secara umum ditemukan bahwa laju inflasi ini disebabkan karena adanya perimntaan pada saat perayaan hari keagaman dan menjelang akhir tahun. Peningkatan laju inflasi tertinggi terjadi pada bahan makanan yang diikuti oleh kelompok perumahan, listrik, air, gas dan bahan bakar.

Sementara itu pada sektor Produk Domestik
Regi-onal Bruto (PDRB) yang dipahami sebagai jumlah nilai barang dan jasa yang diproduksikan/dihasilkan dari seluruh sektor perekonomian di Kota Bitung dalam kurung waktu satu tahun berdasarkan data yang ada menunjukkan adanya empat sektor baisi yang mempunyai nilai lebih dari satu yaitu sektor pertanian, sektor industri pengolahan, sektor gas/listrik dan air bersih, sektor angkutan dan komunikasi. Kondisi ini memberikan makna bahwa sektor tersebut diatas memberikan konribusi lebih besar dibandingkan dengan sektor lainnya di Kota Bitung. Atas kenyataan ini menjadikan Pemerintah Kota Bitung menetapkan sebagai sektor unggulan. Dengan berjalannya waktu,struktur ekonomi Kota Bitung sampai dengan saat ini masih didominasi oleh empat sektor yaitu angkutan dan komunikasi, indusri pengolahan, pertanian dan bangunan. Keempat sektor inilah yang menjadikan PDRB Kota Bitung mengalami peningkatan dari tahun ke tahun yang juga diikui pada nilai secara rill yang sejak ahun 2009 mengalami peningkatan leih dari 0,06\% seiap tahunnya, lihat Bappeda Kota Bitung, 2010.

Pada aspek pendapatan perkapita dan pemerataan distribusi pendapatan dalam memahami kerangka ekonomi Kota Bitung harus diakui bahwa pertumbuhan ekonomi suau daerah belum tentu menunjukkan peningkatan kemakmuran masyarakatnya. Indiktor kesejahtraan juga ditentukan oleh pemerataan akan hasil-hasil pembangunan. Pertumbuhan ekonomi yang tinggi yang diikuti dengan pertumbuhan penduduk yang tinggi pula menyebabkan tidak meningkatnya pendapatan perkapita. Demikian pula dengan pemerataan kesejahtraan dimana tingginya laju pendapatan tidak selalu diikuti oleh meratanya pendapatan yang diterima oleh masyarakat.

Kondisi ekonomi nasional yang sampai saat ini menunjukkan pada perkembangan yang semakin membaik memberikan dampak pula bagi perkembangan indikator makro ekonomi Kota Bitung. Hal ini ditandai dengan semakin berkurangnya dampak krisis ekonomi global terhadap perekonimian Kota Bitung dimana kondisi ekonomi Kota Bitung mulai tahun 2009 sampai dengan saat ini terus mengalami peningkatan dimana mampu mencapai angka 6,09\% dan selalu berada di atas rata-rata perekonomian kabupaten/kota lainnya yang ada di Provinsi Sulawesi Utara kecuali Kota Manado. Kondisi ini juga berdampak pada peningkatan pendapatan masyarakat Kota Bitung.

PDRB per kapita Kota Bitung yang cukup menarik dijadikan kajian yaitu pada ahun 2008 sebesar Rp. 17.380.897. angka ini menunjukkan besarnya produkivitas penduduk pada tahun 2008. Sedangkan angka perr kapita adalah 13.055.746. angka ini merupakan angka dasar harga berlaku artinya tidak mempertimbangkan perubahan harga. Jika mempertimbangkan perubahan harga sejak tahun 2000 sebagai tahun dasar maka PDRB perkapita adalah sebesar Rp. 10.796.445 dan pendapatan perkapitanya sebesar Rp. 9.639.561 yang artinya baik produktivitas maupun pendapatan perkapira 
menunjukkan adanya kenaikan rill dibandingkan pada tahun 2007 yang masing-maisng nilainya Rp. 10.460 .482 dan Rp. 9.331.989.

Pertumbuhan ekonomi yang ideal adalah pertumbuhan ekonomi yang dapat melampaui pertumbuhan penduduk. Dengan laju pertumbuhan penduduk Kota Bitung yang tergolong tinggi yaitu 2,98\% pertahun pada periode 1990-2000 dan meningkat menjadi $3.28 \%$ pada tahun 2010 maka pertumbuhan ekonomi pun harus mengimbangi laju pertumbuhan penduduk. Dengan adanya pertumbuhan ekonomi yang lebih tinggi dibandingkan dengan pertumbuhan penduduk maka dapat diartikan adanya peningkatan pada masyaraka secara makro. Dikatakan secara makro karena belum adanyajaminan pemerataan dari peningkatan pendapatan terlihat dari perkembangan perkapita terjadi sedikit kenaikan yaitu Rp. 12.204.705 menjadi Rp. 13.055.746 perkapita. Olehnya menjadi tangungjawab pemerintah untuk terus meningkakan pertumbuhan ekonomi dengan memanfaatkan peluang yang dimiliki oleh Kota Bitung dalam Kawasan Pengembangan Ekonomi Terpadu untuk erus diingkakan sehingga penduduk miskin dapat semakin berkurang dan kesejahraan masyarakat akan semakin meningkat.

Pada aspek tenaga kerja dan pengangguran menjadi suatu tantangan dalam kaitannya dengan pertumbuhan ekonomi Kota Bitung. Dari data Badan Pusat Statistik Kota Bitung Tahun 2008, penduduk usia kerja di Kota Bitung sebanyak 129.600 yang terdiri dari golongan angkatan kerja 79.742 orang (68.695 penduduk yang bekerja dan 11.047 penduduk pengangguran terbuka) dan golongan bukan angkaan kerja sebanyak 49.858 orang (9.452 penduduk bersekolah, 27.479 penduduk mengurus rumah tangga dan 12.972 lainnya). Data jumlah penduduk yang termasuk dalam golongan angkatan kerja menggambarkan tingkat partisipasi angkatan kerja, dimana untuk Kota Bitung 68.695 orang atau $87.1 \%$. upaya untuk menjadikan tenaga kerja sebagaimana data diatas menopang perumbuhan ekonomi dalam kerangka ekonomi makro akan sangat ditentukan oleh tingkat dan kualitas pendidikan yang dimiliki oleh enaga kerja tersebut. Tingkat pendidikan formal yang mendominasi lapangan kerja di Kota Bitung hingga saat ini adalah enaga kerja berpendidikan SMP-SMU. Dilihat dari penguasaan keterampilan/keahlian sehingga modal unuk melakukan kreatifitas dan inovasi dapat dikaakan belum memadai.

Sementara itu pengelolaan keuangan daerah merupakan juga salah satu aspek dalam kerangka ekonomi makro daerah. Dalam rangka menjalankan tugas-tugas pemerintahan dan pelaksanaan pembangunan maka dukungan dana menjadi hal yang sangat penting bagi kemauan dan keberhasilan suatu daerah. Pendapatan asli daerah, dana bagi hasil, dana alokasi umum dan dana alokasi khusus merupakan sumber pendapatan dalam rangka memenuhi pembiayaan pembangunan daerah. Dengan segala potensi dan keunggulan sumberdaya, maka masing-masing daerah berlomba meningkatkan aktivitas pembangunan yang diarahkan untuk meningkatkan kesejahraan masyarakat. Dalam posisi Kota Bitung yang terus mengalami peningkatan pada APBD dan penilaian baik pada pengelolaan anggaran memberi makna bahwa pengelolaan keuangan daerah Kota Bitung menopang kerangka ekonomi makro daerah.

Kawasan Pengembangan Ekonomi Terpadu (KAPET) adalah wilayah geografis dengan batas-batas tertentu yang memiliki potensi untuk cepat tumbuh dan mempunyai sektor unggulan yang dapat mengerakkan pertumbuhan ekonomi wilayah dan sekitarnya dan memerlukan dana investasi yang besar bagi pengembangannya.Adapun tujuan dari pembentukan Kawasan Pengembangan Ekonomi Terpadu (KAPET) adalah pemerataan pembangunan dan hasil-hasilnya ke seluruh wilayah Indonesia dengan memberikan peluang kepada dunia usaha agar mampu berperan serta dalam kegiatan pembangunan di Kawasan Timur Indonesia yang relatif tertinggal dan beberapa lainnya di Kawasan Barat Indoensia. Inti dari pendekatan Kawasan Pengembangan Ekonomi Terpadu (KAPET) yang mendorong terbentuknya suatu kawasan yang berperan sebagai penggerak utama (prime mover) pengembangan wilayah. Oleh karenanya maka pemilahan kawasankawasan pembangunan dengan menentukan prioritas atas suatu kawasan merupakan strategi agar percepatan pembangunan dapat dilakukan.

Mewujudkan keberadaan Kawasan Pengembangan Ekonomi Terpadu (KAPET) maka diperlukannya peran pemerintah dalam menggerakkan perekonomian daerah. Harus diakui bahwa pemerintah baik pusat maupun daerah memiliki peran yang sangat penting dalam perekonomian daerah. Kerangka ekonomi Kota Bitung dalam Kawasan Pengembangan Ekonomi Terpadu (KAPET) tidak akan nampak dan memberikan arti tanpa peran nyata dari pemerintah.

Sebuah perekonomian ideal yang kompetitif sempurna terjadi pada pengaturan alokasi sumberdaya bersumber dari pertukaran sukarela antara barang dan uang pada harga pasar akan menghasilkan kuantitas maksimum barang dan jasa dari segenap sumber daya yang tersedia dalam perekonomian tersebut. Namun dalam kenyataan sehari-hari, pasar tidak selalu hadir dalam wujudnya yang ideal ketika tidak adan camput tangan pemerintah. Pada prakteknya, perekonomian pasar seringkali terlilit polusi dan monopoli seiring dengan melonjaknya inflasi atau pengangguran yang pada prakteknya pula, distribusi pendapatan dalam masyarakat laissez-faire sangat tidak merata. Untuk mengatasi kelemahan tersebut pemerintah perlu mengambil peranan penting dalam perekonomian yang salah satunya adalah memacu pertumbuhan ekonomi secara makro dan memelihara stabilitasnya.

Pemerintah yang baik harus senantiasa berusaha memperbaiki kegagalan-kegagalan pasar, misalnya 
dengan mencegah monopoli dan eksternalitas negatif demi terpacunya efisiensi. Pemerintah juga harus memperjuangkan pemerataan melalui program perpajakan dan redistribusi pendapatan untuk kelompok atau golongan masyarakat tertentu sebagaimana yang diamanakan dalam tugas pengelola Kawasan Pengembangan Ekonomi Terpadu (KAPET). Pemerintah harus menggunakan perangkat perpajakan, pembelanjaan dan peraturan moneter untuk menggapai stabilitas dan pertumbuhan ekonomi, mengurangi laju inflasi dan pengangguran serta memacu pertumbuhan ekonomi secara keseluruhan.

Menurut Jones(1996:48) peran pemerintah dapat digolongkan menjadi dua, yaitu secara langsung dan secara tak langsung. Pengendalian secara langsung diantaranya adalah masalah penerimaan dan pengeluaran pemerintah. Sementara pengendalian secara tak langsung diantaranya berhubungan dengan masalah tingkat inflasi, tingkat pertumbuhan ekonomi, tingkat pengangguran serta nilai tukar. Sementara itu instrumen yang digunakan pemerintah untuk mempengaruhi perekonomian, salah satu diantaranya adalah pembelanjaan atau pengeluaran pemerintah.

Pengertian pertumbuhan ekonomi seringkali dibedakan dengan pembangunan ekonomi. Pertumbuhan ekonomi bersangkut-paut dengan proses peningkatan produksi barang dan jasa dalam kegiatan ekonomi masyarakat, sementara pembangunan mengandung arti yang lebih luas. Djojohadikusumo (1994:78) mengungkapkan bahwa proses pembangunan mencakup perubahan pada komposisi produksi, perubahan pada pola penggunaan (alokasi) sumber daya produksi diantara sektor-sektor kegiatan ekonomi, perubahan pada pola distribusi kekayaan dan pendapatan diantara berbagai golongan pelaku ekonomi, perubahan pada kerangka kelembagaan dalam kehidupan masyarakat secara menyeluruh. Namun demikian pertumbuhan ekonomi merupakan salah satu ciri pokok dalam proses pembangunan, hal ini diperlukan berhubungan dengan kenyataan adanya pertambahan penduduk. Djojohakusumo (1994:65) lebih lanjut menjelaskan bahwa bertambahnya penduduk dengan sendirinya menambah kebutuhannya akan pangan, sandang, pemukiman, pendidikan dan pelayanan kesehatan.

Olehnya Blakely (1994:99) mengemukakan akan pentingnya peran pemerintah, dengan mengemukakan sejumlah faktor yang mempengaruhi pembangunan daerah. Faktor-faktor tersebut adalah sumber daya alam, tenaga kerja, investasi modal, kewirausahaan, transportasi, komunikasi, komposisi sektor industri, teknologi, pasar ekspor, situasi perekonomian internasional, kapasitas pemerintah daerah, pengeluaran pemerintah dan dukungan pembangunan. Sehingga guna menimgkatkan pembangunan di sector ekonomi dengan didangunnya kerangka ekonomi makro daerah maka Kota Bitung mampu mewujudkan visi sebagai kota industry, maritime dan bahari yang memiliki sumber daya manusia yang handal, mandiri dan sejahtera, aman, demokratis dan religius.

Sekalipun memang harus diakui bahwa kondisi kerangka perekoniomian makro Kota Bitung juga tidak dapat dipisahkan oleh perkembangan lingkungan eksternal dan internal. Dorangan eksternal bagi perkembangan ekonomi darah antara lain berasal dari situasi dan kondisi perekonomian nasional yang dipengaruhi oleh perekonomian dunia. Sementara dorongan internal seperti pertumbuhan ekonomi tahunan, fasilitasinfrastruktur dan fasilitas penunjang lainnya, koordinasi kerja pemerintah dan stabilitas keamanan daerah. Pemerintah Kota Bitung terus mencermai berbagai factor lingkungan yang bisa menjadi kekuatan dan peluang namun juga dapat menjadi tanangan dan hambatan dalam rangka upaya pemerintah meningkatkan perekonomian daerah bagi kesejahtraan warga masyarakat.

\section{SIMPULAN}

Jika memperhatikan kerangka ekonomi makro Kota Bitung di Kawasan Pengembangan Ekonomi Terpadudari pertumbuhan ekonomi dan kontribusi sektoral maka dapat dibagi ke dalam tiga kelompok sektoral yaitu sektor primer, sekunder dan tersier. Sektor primer terdiri dari sector pertanian dan sektor perambangan dan galian, sektor sekunder merupakan sektor yang didalamnya sudah ada proses pebgelolaan sehingga mencakup sektor industri, lisrik dan air bersih dan bangunan/konstruksi. Sedangkan sektor tersier yaitu sektor-sektor lainnya yang lebih mengarah kepada pelayanan yang mencakup sektor perdagangan, hotel dan restoran, angkuan dan komunikasi, bank dan lembaga keuangan, persewaan dan jasa perusahaan serta sector jasa lainnya.

Melihat berbagai kemajuan yang telah dicapai serta tantangan yang dapat dihadapi kedepan maka untuk memperkuat kerangka ekonomi makro Kota Bitung di Kawasan Pengembangan Ekonomi Terpadu perlu mengurangi pengangguran dan meningkatkan kualitas tenaga kerja, menurunkan jumlah penduduk miskin, meningkakan produksi pada sector angkutan, komunikasi, industri pengolahan dan perikanan serta melakukan pembenahan pada berbagai kendala yang menghambat peningkatan produksi dan infestasi sehingga dengan bertumbuhnya iklim investasi dari swasta maka perumbuhan ekonomi Kota Bitung akan terus mengalami peningkatan.

\section{DAFTAR PUSTAKA}

Bappeda Kota Bitung. 2010. Profil Perekonomian Kota Bitung.Bitung: Badan Perencanaan Pembangunan Daerah.

Bernard, J. 1996. Financial Management In The Public Sector, England: Mc-Graw Hill Companies. 
Blakely, E. 1994. Planning Local Economic Development, Theory and Practice, Second Edition. United State Of America: Sage Publications.

Djojohadikusumo, S. 1994. Perkembangan Pemikiran Ekonomi, Dasar Teori Ekonomi Pertumbuhan dan Ekonomi Pembangunan, Jakarta : LP3ES.
Farida Ai. Siti. Sistim Ekonomi Indonesia. Bandung: Pustaka Setia.

Keputusan Presiden Nomor 150 Tahun 2000 tentang Kawasan Pengembangan Ekonomi Terpadu

Mathew, M.B and Huberman, A.M. 1992. Qualitative Data Analysis. United State Of America : Sage Publications Inc. 